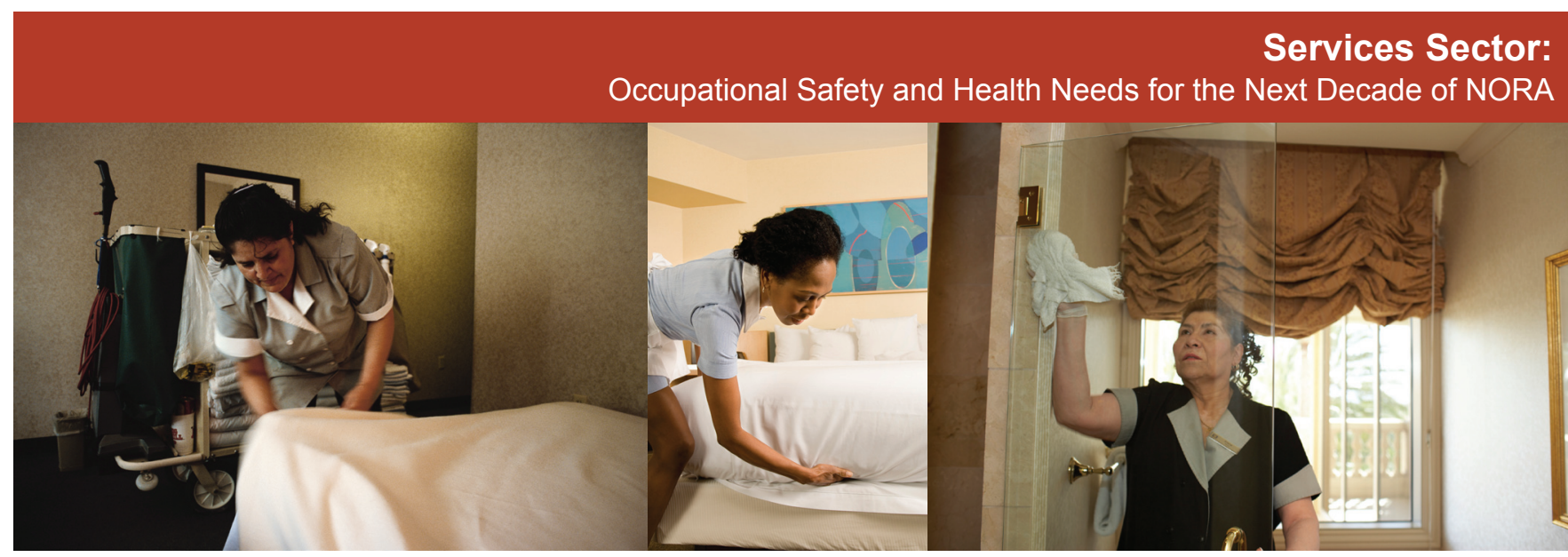

\title{
Safety and Health among Hotel Cleaners
}

Improvements through partnerships and research

The National Occupational Research Agenda (NORA) is a partnership program to promote innovative research and improve workplace practices. Unveiled in 1996, NORA is a framework for guiding occupational safety and health research and interventions throughout the nation. NORA stakeholders collaborate to identify critical workplace issues in industry sectors. The National Institute for Occupational Safety and Health (NIOSH) convened a number of these partners to develop the National Services Agenda, which includes safety and health goals for the Accommodations Industry. Groups such as unions, worker organizations, government agencies, and hotel/motel associations can build partnerships to implement these goals and help ensure that hotels are safe for all employees.

\section{Who works in hotel cleaning?}

Nearly 1.8 million people worked in the Traveler/ Accommodations industry in 2008, including more than 400,000 hotel room cleaners ${ }^{1}$. Tasks performed by hotel room cleaners include dusting, vacuuming, changing linens and making beds, scrubbing bathrooms, cleaning mirrors, and disposing of trash. Most cleaners are women, and many are immigrants and minorities. According

\footnotetext{
BLS [2009]. May 2009 national industry-specific occupational employment and wage estimates: NAICS 721100 - Traveler Accommodation. Washington, DC: Bureau of Labor Statistics. http://www.bls.gov/oes/current/naics4_721100.htm\#37-0000
}

to a recent academic study, housekeepers had the highest rates of injury of all jobs studied in sampled hotels. Furthermore, among housekeepers, Hispanic females had the highest rate of injury ${ }^{2}$.

\section{What are the important safety and health issues in the Accommodations Subsector?}

Workplace hazards from hotel cleaning may result in the following ${ }^{3-6}$ :

- Musculoskeletal disorders from bending, pushing carts, and making beds

- Traumatic injuries from slips, trips, and falls

- Respiratory illnesses from cleaning products that contain substances such as irritant aerosols and bleaching agents

- Skin reactions from detergents and latex

- Infectious diseases from agents such as biological waste (e.g., feces and vomit) and bloodborne pathogens found on broken glass and uncapped needles

Buchanan S, Vossenas P, Krause N, Moriarty J, Frumin E, Shimek JM, Mirer F, Orri P, Punnett L [2010]. Occupational injury disparity in the US hotel industry. Am J Ind Med 53(2):116-125.

Charles LE, Loomis D, Demissie Z [2009]. Occupational hazards experienced by cleaning workers and janitors: a review of the epidemiologic literature. Work 34(1):105-116.

Krause N, Scherzer T, Rugulies R [2005]. Physical workload, work intensification, and prevalence of pain in low wage workers: results from a participatory research project with hotel room cleaners in Las Vegas. Am J Ind Med 48(5):326-337. Krause N, Rugulies R, Maslach C [2010]. Effort-reward imbalance at work and selfrated health of Las Vegas hotel room cleaners. Am J Ind Med 53:372-386.

${ }^{6}$ Seidner A [2010]. Overview of an insurance carrier's service sector data. In: Utterback D, Schnorr T. Use of workers' compensation data for occupational injury and illness prevention. NIOSH, DOL, BLS.
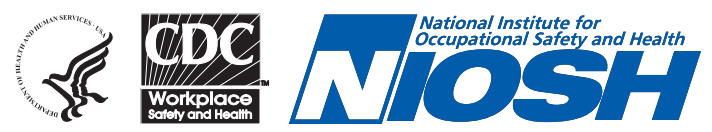

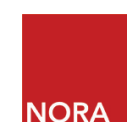

The National Institute for Occupational Safety and Health (NIOSH) is working with many partners to develop an updated National Occupational Research Agenda (NORA). The NORA Services Sector Council is a group of partners working to develop a national agenda for the Services Sector. 
- Occupational stress due to workloads, job insecurity, low pay, and discrimination

\section{How can you help improve safety and health among hotel cleaners?}

Organizations and individuals can help improve the safety and health of hotel cleaners in the United States. We invite you to participate in the following activities:

- Identify and evaluate hazards and adopt interventions to prevent work-related injuries and illnesses in the hotel environment.

- Evaluate the quality and ensure maintenance of equipment used in hotel cleaning operations.

- Encourage the use of ergonomic carts and vacuum cleaners, and long-handled tools like mops and scrub brushes; and inform suppliers about the best equipment for cleaners.

- Conduct research on what guests can do to improve the work environment for room cleaners.

- Partner with OSHA, NIOSH, labor, and others to study why disparities exist in injury rates among room cleaners and what remedies are effective, and to quickly implement available remedies.

- Lead a work group to address priority issues related to a strategic goal to help inform employers and policy makers about hazards and interventions.

- Assist in the design of an effective system to track occupational injuries and illnesses in the hotel/motel industry.

- Represent a partner organization to work on a goal implementation plan.
- Provide input to the NORA Coordinator on the implementation of goals (noracoordinator@cdc. gov) and suggest important issues to consider for future goals.

\section{What are the Sector Goals for Accommodations?}

The NORA Services Sector Council developed strategic goals for the Accommodations Subsector to address priority workplace safety and health issues. The Council will ensure progress and track accomplishments through 2016. Partnerships are needed to achieve these goals to reduce work-related injury, illness, and death among hotel cleaners:

- Reduce the incidence and severity of occupational injuries by $20 \%$ as measured in lost work days among hotel and motel workers.

- Reduce by $20 \%$ the incidence and severity of occupational illness and morbidity that result in lost work days among hotel and motel workers.

- Eliminate health disparities for priority population workers in the hotel and motel industry.

\section{Contacts}

The above is a synopsis of the Accommodations goals established by the NORA Services Sector Council. To participate or to receive additional information please contact:

noracoordinator@cdc.gov

Please visit the NORA Web site for more information about NORA, the NORA Services Sector, or to obtain the complete text of the National Services Agenda. www.cdc.gov/niosh/nora/ 